\title{
Life span, dispersal and age of nesting Great Grey Owls Strix nebulosa lapponica in Sweden
}

\author{
Livslängd, spridning och ålder hos häckande lappugglor Strix nebulosa lapponica \\ i Sverige
}

ROAR SOLHEIM \& OVE STEFANSSON

\begin{abstract}
3073 Great Grey Owls were banded in Sweden in 19552012. 416 were controlled at least once $(54.6 \%)$ or recovered dead $(45.4 \%)$. Three birds banded as nestlings were recovered in their 17th calendar year. Most birds were recovered during first year of life. Only 4 females were controlled breeding as $2 \mathrm{CY}$ birds. $91.3 \%$ of birds controlled as first time breeders were at least 4CY. Birds banded as nestlings and recovered dead between September and July moved $100.8 \mathrm{~km}$ (mean) with a median distance of $64 \mathrm{~km}$. Juveniles controlled alive moved 45.9 $\mathrm{km}$ (mean) with a median distance of $23 \mathrm{~km}$ during first year of life. Maximum natal dispersal was $650 \mathrm{~km}$. Median natal dispersal for females was $40 \mathrm{~km}$, between 7

$\mathrm{km}$ and $115 \mathrm{~km}$ depending on longevity from hatching to control. Females at ages $2 \mathrm{CY}, 5 \mathrm{CY}, 8 \mathrm{CY}$ and $11 \mathrm{CY}$ had the lowest median natal dispersals. Median secondary dispersal distances (from one nest to a later nestsite) for females lay between $0 \mathrm{~km}$ and $9 \mathrm{~km}$. For males both mean and median secondary dispersal distances were less than $3 \mathrm{~km}$.

Roar Solheim, Agder Natural History Museum, P. O. Box 1887 Gimlemoen, 4686 Kristiansand, Norway. $r$ solhe3@online.no

Ove Stefansson, Bindevägen 5, 96137 Boden, Sverige. lappugglan@telia.com
\end{abstract}

Received 12 Ocrober 2016, Accepted 7 November 2016, Editor: S. Svensson

\section{Introduction}

The Great Grey Owl Strix nebulosa lapponica has expanded in a south and southwesterly direction since the late 1990s in the northwestern corner of its Palearctic distribution (Lawicki et al. 2013). The expansion southwards in Fennoscandia started between the mid-1960s and early 1990s (Stefansson 1997, Sulkava \& Huhtala 1997, Solheim 2009).

Since the first breeding record in Eastern Norway in 1989, the reports of Great Grey Owl sightings gradually increased also in Norway (Solheim 2009). The number of recorded nests or breeding attempts in Norway literally exploded after 2009, resulting in more than 60 nests or breeding attempts recorded in Hedmark county in 2014 (Solheim 2014a, Berg 2015). Since this expansion is closely linked to the Great Grey Owl population in Sweden, we thought a more detailed analysis and presentation of the Swedish banding material of this species would provide valuable background in the attempts to understand this development. The recently published Finnish Bird Ringing Atlas (Valkama et al. 2014) also inspired ideas for some different analysis than formerly presented (Stefansson 1997 and Supplements I-IV, Fransson et al. 2008).

In spite of its considerable size, the Great Grey Owl feeds almost exclusively on small mammals, with Microtus voles as the dominant prey species, followed by Bank Vole Myodes glareolus and Common Shrew Sorex araneus (Mikkola 1983, Stefansson 1997). Their dispersal and movement should thus be expected to follow a pattern similar to what has been found for the microtine specialist Tengmalm's Owl Aegolius funereus (Sonerud et al. 1988), and vary according to vole cycles which peak every 3-4 years in the boreal parts of Fennoscandia (e.g. Hanson \& Henttonen 1985, Sonerud 1988). The number of recorded breeding Great Grey Owls typically reach a peak at the top of the vole cycles every 3 to 4 years (Mikkola 1983).

\section{Materials and methods}

Lists of controlled and recovered Great Grey Owls in Sweden for 1955-1996 were first presented by 
Stefansson in the book "Nordanskogens vagabond" (1997), with four later supplements covering the years 1997-2012. This material supplied with control and recovery data up to and including 2015 make the basis for our new compilations. For comparison with Finland, the number of recoveries up to and including 2012 only (398) has been used. We have not analyzed direction of movement, but concentrated on distance moved and age of owls when controlled or recovered. The formerly presented data has been reviewed and updated to correct for former errors.

15 owls banded in Finland have been controlled alive (9) or recovered dead (6) in Sweden, all within the period 1984-2015. Data from these individuals have been incorporated in the presentation of age of first breeders, and dispersal distances.

\section{Results}

From 1955 to 1996 a total of 1715 Great Grey Owls were banded in Sweden (Stefansson 1997). From 1997 to 2012 a total of 1358 Great Grey Owls were banded (Table 1) giving a total of 3073 banded owls as basis for our analysis. For the latter period, the material could be split in birds banded as nestlings $(1083 ; 79.7 \%)$ and adults $(275 ; 20.3 \%)$. A total of 416 individuals were either controlled alive at least once $(227 ; 54.6 \%)$ or recovered dead (189; $45.4 \%$ Figure 1 ), giving a $13.5 \%$ recovery rate. For the period 1997-2012 recoveries have been split to year of banding (Table 1), with recovery rates from each year-class varying from $4.3 \%$ to $50.0 \%$. The three years of highest recovery rates $(1997,2000$ and 2012) are the years with some of the lowest numbers of banded individuals $(13,9$ and 8 individuals respectively). Although only 8 juveniles were banded these years, one of these was actually controlled alive, while none were recovered dead (Table 1). Of 16 birds banded as adults these three years, 3 were later controlled alive while 6 were recovered dead. The overall recovery rate (dead and live controls) from the period $1997-2012$ is $10.9 \%$.

\section{Longevity}

A total of 122 owls banded as nestlings were later recovered dead, with 3 birds recovered in their 17th calendar year (Figure 2). Most birds were however recovered during their first (33) or second

Table 1. Great Grey Owls banded in Sweden as nestlings or adults in 1997-2012 (B), and later controlled alive (C) or recovered dead (D).

Lappugglor ringmärkta som boungar eller vuxna häckfåglar i Sverige 1997-2012 (B), och senare kontrollerade (C) eller åtefunna döda (D).

\begin{tabular}{|c|c|c|c|c|c|c|c|c|c|c|c|c|}
\hline \multirow[t]{2}{*}{ Year } & \multicolumn{3}{|c|}{$\begin{array}{l}\text { Banded as nestlings } \\
\text { Märkta som ungar }\end{array}$} & \multicolumn{3}{|c|}{$\begin{array}{l}\text { Banded as adults } \\
\text { Märkta som vuxna }\end{array}$} & \multicolumn{3}{|c|}{ Total } & \multicolumn{3}{|c|}{$\begin{array}{l}\% \text { of total } \\
\% \text { av total }\end{array}$} \\
\hline & $\mathrm{B}$ & $\mathrm{C}$ & $\mathrm{D}$ & B & $\mathrm{C}$ & $\mathrm{D}$ & B & $\mathrm{C}$ & $\mathrm{C}$ & $\mathrm{C}$ & $\mathrm{D}$ & $\mathrm{C}+\mathrm{D}$ \\
\hline 1997 & 0 & 0 & 0 & 13 & 0 & 3 & 13 & 0 & 3 & - & 23.1 & 23.1 \\
\hline 1998 & 73 & 6 & 5 & 24 & 2 & 4 & 97 & 8 & 9 & 8.2 & 9.3 & 17.5 \\
\hline 1999 & 44 & 5 & 2 & 9 & 1 & 1 & 53 & 6 & 3 & 11.3 & 5.7 & 17.0 \\
\hline 2000 & 6 & 1 & 0 & 3 & 2 & 0 & 9 & 3 & 0 & 33.3 & - & 33.3 \\
\hline 2001 & 89 & 7 & 0 & 21 & 8 & 3 & 110 & 15 & 3 & 13.6 & 2.7 & 16.4 \\
\hline 2002 & 69 & 1 & 1 & 15 & 3 & 1 & 84 & 4 & 2 & 4.8 & 2.4 & 7.1 \\
\hline 2003 & 21 & 0 & 1 & 3 & 0 & 1 & 24 & 0 & 2 & - & 8.3 & 8.3 \\
\hline 2004 & 193 & 7 & 11 & 40 & 11 & 3 & 233 & 18 & 14 & 7.7 & 6.0 & 13.7 \\
\hline 2005 & 78 & 0 & 3 & 12 & 0 & 1 & 90 & 0 & 4 & - & 4.4 & 4.4 \\
\hline 2006 & 17 & 1 & 0 & 18 & 2 & 2 & 35 & 3 & 2 & 8.6 & 5.7 & 14.3 \\
\hline 2007 & 111 & 3 & 4 & 32 & 4 & 1 & 143 & 7 & 5 & 4.9 & 3.5 & 8.4 \\
\hline 2008 & 53 & 0 & 2 & 15 & 1 & 1 & 68 & 1 & 3 & 1.5 & 4.4 & 5.9 \\
\hline 2009 & 1 & 0 & 0 & 7 & 1 & 0 & 8 & 1 & 0 & 12.5 & - & 12.5 \\
\hline 2010 & 121 & 2 & 2 & 29 & 10 & 4 & 150 & 12 & 6 & 8.0 & 4.0 & 12.0 \\
\hline 2011 & 205 & 2 & 6 & 28 & 2 & 0 & 233 & 4 & 6 & 1.7 & 2.6 & 4.3 \\
\hline 2012 & 2 & 0 & 0 & 6 & 1 & 3 & 8 & 1 & 3 & 12.5 & 37.5 & 50 \\
\hline Sum & 1083 & 35 & 37 & 275 & 48 & 28 & 1358 & 83 & 65 & 6.1 & 4.8 & 10.9 \\
\hline
\end{tabular}




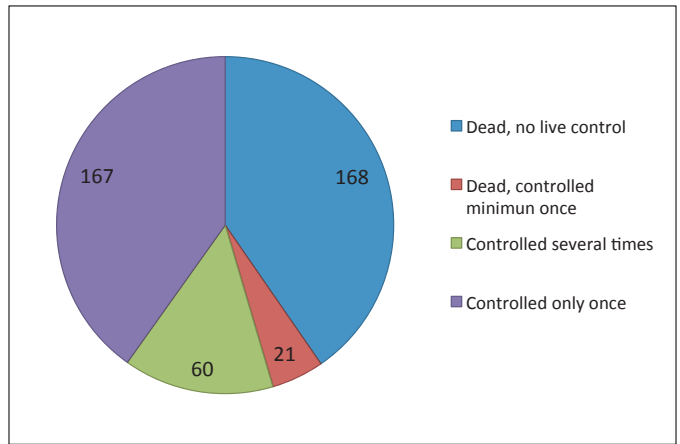

Figure 1. Recoveries and controls of 416 Great Grey Owls banded in Sweden.

Aterfynd och kontroller av 416 lappugglor ringmärkta i Sverige.

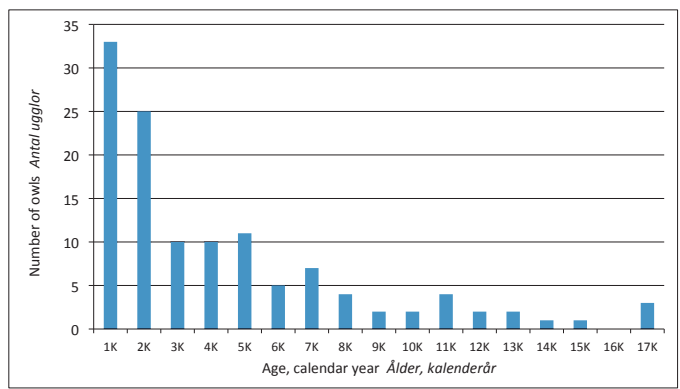

Figure 2. Age at recovery of dead Great Grey Owls banded as nestlings.

Ålder vid återfynd av döda lappugglor ringmärkta som boungar.

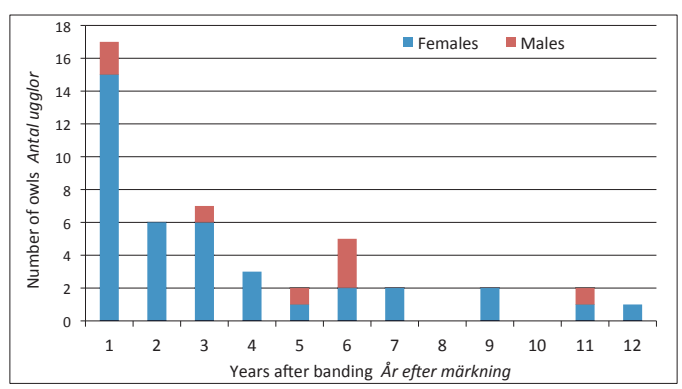

Figure 3. Years after banding for recoveries of dead Great Grey Owls banded as nesting adults.

Ar efter märkning för återfynd av döda lappugglor ringmärkta som vuxna häckfåglar.

(25) calendar years, with numbers recovered steadily declining thereafter. Recovery of dead birds banded as nesting adults comprise of 39 females and 8 males, which also show a declining number of recoveries with age (Figure 3 ). The oldest bird from this group was a female recovered 12 years

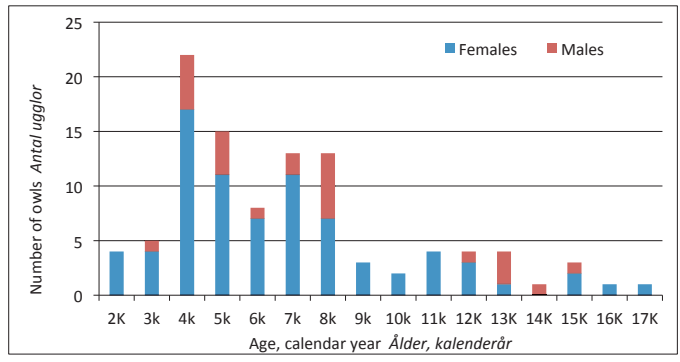

Figure 4. Age of Great Grey Owls banded as nestlings when first controlled as nesting adults.

Alder vid förstagångskontroll som häckande fågel för lappugglor märkta som boungar.

after banding. Her exact age is however not known, since aging of fully grown Great Grey Owls according to molt patterns (Suopajärvi \& Suopajärvi 1994, Solheim 2011) was not well known at the time for banding of most of the owls in this material.

\section{Age of first time breeders}

Seventy-six females and 27 males banded as nestlings were later controlled as nesting birds at least once (Figure 4). Most birds were controlled for the first time in their fourth calendar year or later. Four females were found breeding as one year old birds $(2 \mathrm{~K})$, and 4 females and 1 male as two year olds $(3 \mathrm{~K})$. The oldest first time control breeder banded as a nestling was a female controlled in her 17th calendar year (16 years old). Another female banded as nestling was controlled breeding as $5 \mathrm{~K}, 10 \mathrm{~K}$, $16 \mathrm{~K}$ and finally as $17 \mathrm{~K}$ bird. Of all controlled nesting birds themselves banded as nestlings, 91.3\% were at least three years old $(4 \mathrm{~K}+)$ when controlled nesting for the first time. The figure shows a tendency for more birds controlled at age classes $4 \mathrm{~K}$ $5 \mathrm{~K}, 7 \mathrm{~K}-8 \mathrm{~K}$ and $11 \mathrm{~K}-12 \mathrm{k}(13 \mathrm{~K})$.

\section{Dispersal}

Juveniles

Fifty of a total of 52 juveniles recovered dead or controlled alive between 1 August and 30 June the following year dispersed less than $250 \mathrm{~km}$ from where they were banded as nestlings (Figure 5). One individual was found dead $410 \mathrm{~km}$ from the hatch site, and one was shot $420 \mathrm{~km}$ away in Russia. Birds recovered before the end of September were mostly found very close to their hatch site. Mean distance for 29 birds found dead after Sep- 


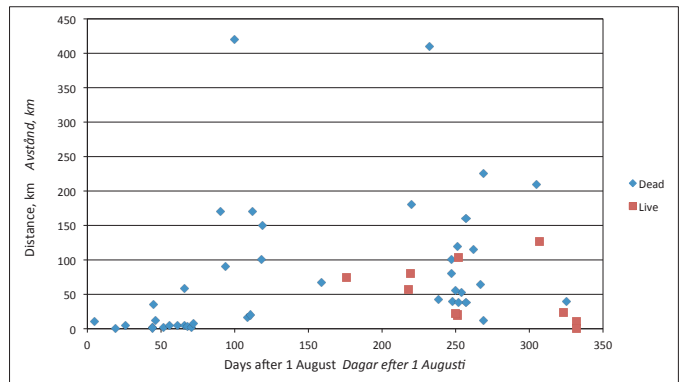

Figure 5. Distance in $\mathrm{km}$ and days after 1 August at time of recovery or control of Great Grey Owls banded as nestlings. Avstånd $i \mathrm{~km}$ och dagar efter den 1 augusti vid tiden för återfynd eller kontroll av lappugglor ringmärkta som boungar.

tember, was $100.8 \mathrm{~km}$, with a median distance of $64 \mathrm{~km}$.

Ten juveniles were controlled alive between 23 January and 2 June in their second calendar year. Two individuals were controlled $126 \mathrm{~km}$ and 103 $\mathrm{km}$ from the hatch site respectively, while the rest were all controlled within $80 \mathrm{~km}$ away. Mean distance moved for these controlled birds was 45.9 $\mathrm{km}$, with a median distance of $23 \mathrm{~km}$.

\section{Full-grown birds}

A total of 103 birds banded as nestlings were later controlled as breeders ( 76 females and 27 males). The maximum natal dispersal recorded was a female banded in 1982 and controlled in 1987 (6K), which moved $650 \mathrm{~km}$. Next in line was another female controlled as $13 \mathrm{~K}$ after dispersing $230 \mathrm{~km}$. Mean distance of natal dispersal for all adults is shown linked to age of the bird at first control (Figure 6), and varied between $29.9 \mathrm{~km}$ and $114.4 \mathrm{~km}$.

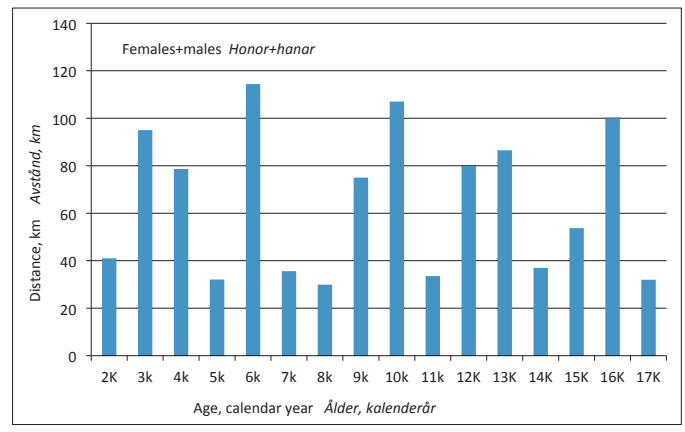

Figure 6. Mean distance in $\mathrm{km}$ between hatch site and nest site when controlled as nesting for the first time, female and male pooled.

Medelavstånd $i \mathrm{~km}$ mellan kläckningsplats och platsen för första kontroll som häckfågel för lappugglor av båda könen.

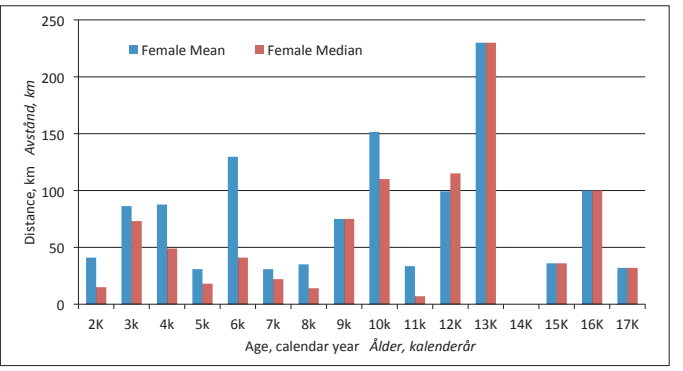

Figure 7. Mean and median distance in $\mathrm{km}$ between hatch site and nest site for Great Grey Owl females when first controlled as nesting birds.

Medel- och medianavstånd $i \mathrm{~km}$ mellan kläckningsplats och boplats vid förstagångskontroll som häckfågel för lappugglehonor.

For females only, the mean natal dispersal varied between $30.8 \mathrm{~km}(7 \mathrm{~K})$ and $151.5 \mathrm{~km}(10 \mathrm{~K})$, with an overall mean of $72.3 \mathrm{~km}$ (Figure 7). Median values for the females' natal dispersal fell between 7 $\mathrm{km}$ and $115 \mathrm{~km}$, with an overall median of $40 \mathrm{~km}$. The lowest median natal dispersal values for Swedish Great Grey Owl females are for birds recorded nesting for the first time in age classes $2 \mathrm{~K}, 5 \mathrm{~K}, 8 \mathrm{~K}$ and $11 \mathrm{~K}$ respectively.

A total of 135 females (26 banded as juveniles and 109 banded as breeders) were controlled as breeders more than once, some up to 6 times, resulting in a total of 211 controls giving distances between first recorded nest place and later nest places (Figure 8), and covering 1 to 12 years af-

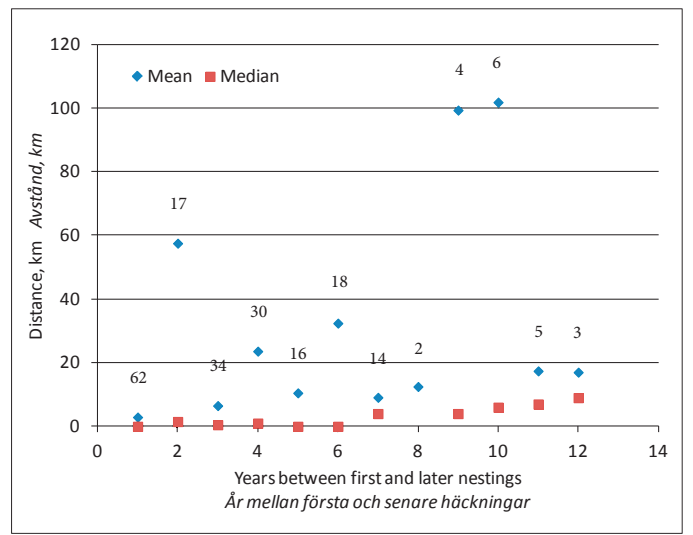

Figure 8. Mean and median distance dispersed in $\mathrm{km}$ between first recorded nesting of females and later nest sites. Number of controlled females is given at each symbol. Medel- och medianavstånd $i \mathrm{~km}$ mellan den första registrerade häckningsplatsen för lappugglehonor och deras senare häckningsplatser. Antal kontrollerade honor anges vid varje symbol. 


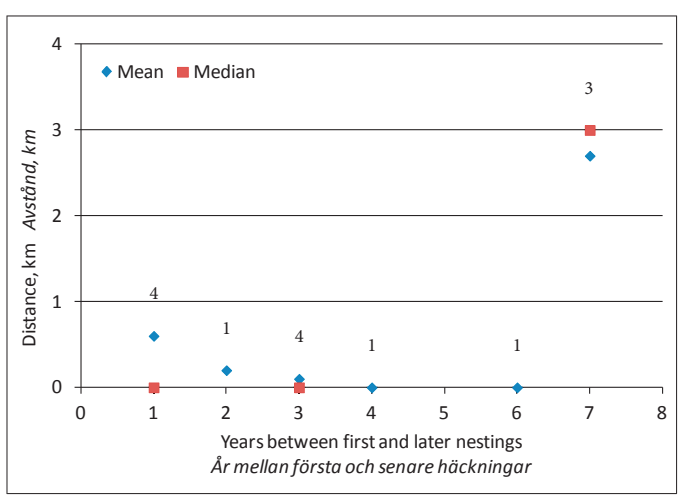

Figure 9. Mean and medain distance dispersed in $\mathrm{km}$ between first recorded nesting of males and later nestsites. Number of controlled males is given at each symbol.

Medel och median avstånd $i \mathrm{~km}$ mellan den försa registrerade häckningsplatsen för lappugglehanar och deras senare häckningsplatser. Antal kontrollerade hanar anges vid varje symbol.

ter first breeding record. Mean dispersal distance moved after first having nested once varies between $2.9 \mathrm{~km}$ and $101.8 \mathrm{~km}$, with an overall mean dispersal distance of $19.6 \mathrm{~km}$. Median secondary dispersal distances however are very low, varying between 0 and $9 \mathrm{~km}$. Only 9 males were controlled as breeders after their first control as nesting birds, resulting in a total of 14 controls only. Both mean and median secondary dispersal distances for males are below $3 \mathrm{~km}$ (Figure 9), spanning 1 to 7 years after the first breeding record.

\section{Discussion}

\section{Recovery and control rates}

The number of Great Grey Owls banded in Sweden 1911-2012 (3091; Fransson et al. 2013) is next to identical to the numbers banded in Finland 19132012 (3110; Valkama et al. 2014). The Swedish material however contains almost twice as many recovered and controlled individuals (398 versus 201). The number of birds controlled alive in Sweden is 3.8 times as high as in the Finnish material (262 versus 69). For birds banded as nestlings and later controlled as breeders the difference is even higher, with 97 individuals controlled in Sweden and only 18 controlled in Finland. These discrepancies can only be explained by a higher effort at catching and controlling fully grown birds in Sweden. The higher number of birds recovered dead of Great Grey Owls banded in Sweden (189 versus 123) may be linked to Sweden having almost twice as many inhabitants as Finland (9.8 versus 5.5 million), thus providing higher probabilities for a dead owl to be found.

\section{Recoveries versus vole cycles}

The highest recovery rates were found for birds banded in typical vole-low years when only a very low number of birds were banded in total $(8,9$ and 13). One might expect a higher probability of finding starved individuals in such years, so it is surprising that the only bird recovered and banded as a nestling from these years was actually controlled as a nesting adult two years after being banded. The adults however follow the expected pattern, with 6 individuals recovered dead and 3 controlled alive out of 16 banded birds.

The distribution of birds banded as nestlings and later recovered dead followed an expected pattern, with most individuals recovered during their first autumn after hatching, and steadily declining thereafter (Figure 2). Since most nestlings are banded in vole peak years (but some also in the previous pre-peak years), they will usually encounter a vole depression as $2 \mathrm{~K}$ (or $3 \mathrm{~K}$ ) birds. Many will meet a slightly increasing vole abundance as $3 \mathrm{~K}$ and definitively as $4 \mathrm{~K}$ birds. The low numbers of dead birds in age classes $3 \mathrm{~K}$ and $4 \mathrm{~K}$ may thus be explained by a higher survival rate for birds which have survived their first two years of life. Even birds banded as nesting adults and later recovered dead are most likely found during the first year after being banded (Figure 3). The total number of recovered adults is however too small to draw any other conclusion than that the oldest one lived 12 years after banding. Since most birds banded as nestlings and later controlled as nesting birds were at least in age group $4 \mathrm{~K}$ or older (Figure 4), this individual may well have lived to be 16 years. This is in accordance with the age of the oldest nesting bird controlled for the first time (Figure 4), and matches the age record in the Finnish material (16 years; Valkama et al. 2014).

\section{Age of nesting birds}

The controls of nesting birds banded as nestlings show that at least some females may start breeding as one year old birds (Figure 4), and at least one male started as two years old. Cramp (1985) gives the same ages of first breeders, quoting Stefansson with age of first breeding probably 2 years, but one female recorded breeding as 1 year old bird $(2 \mathrm{~K})$.

The highest number of birds controlled for the 
first time as nesting adults fell in the age category $4 \mathrm{~K}$. This is in accordance with a vole cycle peaking after 3 years. Interestingly the age distribution peaks again for birds in age catergories $7 \mathrm{~K}-8 \mathrm{~K}$, and even tend to show a peak for ages $11 \mathrm{~K}-13 \mathrm{~K}$. The numbers for these latter age groups are however small, and may be influenced by accidential events. The peaks for age groups $4 \mathrm{~K}$ and $7 \mathrm{~K}-8 \mathrm{~K}$ however follows what would be expected from vole cycles peaking every 3 to 4 years.

\section{Natal dispersal}

In Finland most juveniles recovered during their first year were found less than $50 \mathrm{~km}$ from their hatch site. Juveniles later controlled alive were however encountered closer to their hatch site than the ones recovered dead (Figure 5). This might be caused by these individuals being better hunters and survivors close to their hatch sites when voles decline, but could also be linked to bird banders being more active at catching and controlling birds locally where they band them as nestlings.

Birds banded as nestlings and later controlled as nesting adults showed mean values of natal dispersal between $30 \mathrm{~km}$ and $144 \mathrm{~km}$ (Figure 6), which is in the same magnitude as for juveniles recovered dead during first year of life. Median natal dispersal for Finnish birds banded as nestlings was $48 \mathrm{~km}$ for females $(\mathrm{N}=13)$ and $25 \mathrm{~km}$ for males $(\mathrm{N}=5)$ (Valkama et al. 2014). This is in accordance with an overall median natal dispersal distance for Swedish female owls of $40 \mathrm{~km}$. The lowest median natal dispersal distances found for females in age classes $2 \mathrm{~K}, 5 \mathrm{~K}, 8 \mathrm{~K}$ and $11 \mathrm{~K}$ (Figure 7) can also be interpreted as a result of vole cycles peaking every 3rd year, as found for northern Sweden (Hipkiss et. al 2008). The females breeding as $2 \mathrm{~K}$ birds probably encounter a vole peak the year after they were hatched, and thus disperse short distances from their hatch site. The shorter distances for later age classes may be a result of birds returning to their hatch site or former breeding site during vole peak years.

\section{Breeding dispersal}

When the owls have nested for the first time, both females (Figure 8) and males (Figure 9) are almost stationary regarding nest site, and show median dispersal values to next breeding site mostly close to zero, with maximum $9 \mathrm{~km}$ for females and $3 \mathrm{~km}$ for males. 34 females in Finland which were controlled in two successive breeding sea- sons also moved less than $10 \mathrm{~km}$ (Valkama et al. 2014). While Swedish females seem to breed in the same area even up to 12 years after the first control (maximum distance moved was $102 \mathrm{~km}$ ), Finnish females showed median movement distances of 67 $\mathrm{km}$ with a maximum of $405 \mathrm{~km}$ moved.

\section{Site tenasity or nomadism}

During the microtine low in 2012 which covered most of Fennoscandia, at least $76 \%$ of 144 individuals identified from photographs were juvenile 2K birds (Solheim 2014b). Older birds do however also appear along the coast of southern Norway and Sweden (Solheim 2010), leaving the question open to whether adult birds stay close to their breeding sites during winter, or migrate to better hunting grounds before returning to the breeding areas they have used at least once. To get more data on winter movements, a satellite project was initiated in 2014 and two nesting females were equipped with transmitters (Solheim et al. 2015). While one of them stayed within $26 \mathrm{~km}$ of the nest place of 2014 from February until loosing its transmitter in late May 2015 , the other moved to a new locality $175 \mathrm{~km}$ away where it stayed for one year until the transmitter went silent in February 2016. Hopefully more birds with transmitters will give better data on the Great Grey Owls winter habits in the future.

\section{Acknowledgements}

We thank all bird banders who have put effort in banding and controlling Great Grey Owls.

\section{References}

Berg, T. 2015. Lappugle i Hedmark 2014. Kornkråka 45: 30-32. (Norwegian)

Berg, T., Solheim, R., Wernberg, T. \& Ostby, E. 2011. Lappuglene kom. Vår Fuglefauna 34: 108-115. (Norwegian)

Cramp, S. (ed.) 1985. Handbook of the birds of Europe, the Middle East and North Africa. Vol. IV. Oxford Univ. Press

Fransson, T., Österblom, H. \& Hall-Karlsson, S. 2008. Svensk ringmärkningsatlas. Vol. 2. Stockholm.

Fransson T., Jansson, L., Kolehmainen, T., Kroon, C. \& Wenninger, T. 2013. Ringinform nr 12013 (36), NRM. ISSN 1100-4134.

Hansson, L. \& Henttonen; H. 1985. Gradients in density variations of small rodents: the importance of latitude and snow cover. Oecologia 67: 394-402.

Hipkiss, T., Stefansson, O. \& Hörnfeldt, B. 2008: Effect of cyclic and declining food supply on great grey owls in boreal Sweden. Canadian Journal of Zoology 86(12): 1426-1431. 
Ławicki, Ł., Abramcuk, A. V., Domashevsky, S. V., Paal, U., Solheim, R. Chodkiewicz, T. \& Wozniak, B. 2013. Range extension of Great Grey Owl in Europe. Dutch Birding 35: $145-154$.

Mikkola, H. 1983. Owls of Europe. Poyser.

Solheim, R. 2009. Lappugla - en klimaflyktning på vei sydover? Vår Fuglefauna 32: 164-169. (Norwegian)

Solheim, R. 2010. Kan lappugglor individbestämmas utan infångande och märkning? Vår Fågelvärld 69(2): 8-12. (Swedish).

Solheim, R. 2011. Moult pattern of primaries and secondaries during first and second flight feather molt in Great Grey Owls Strix nebulosa. Ornis Svecica 21: 11-19.

Solheim, R. 2014a. Lappugglan på frammarsch. Vår Fågelvärld 73 (6): 46-50. (Swedish)

Solheim, R. 2014b. Age of Great Grey Owls Strix nebulosa observed in Scandinavia in 2012 as revealed by digital photos in the national species report archives. Ornis Svecica 24: 3-11.

Sonerud, G. 1988. What causes extended lows in microtine cycles? Analysis of fluctuations in sympatric shrew and microtine populations in Fennoscandia. Oecologia 76: 37-42.

Sonerud, G. A., R. Solheim \& K. Prestrud 1988: Dispersal of Tengmalm's Owl Aegolius funereus in relation to prey availability and nesting success. Ornis scand. 19: 178-181.

Solheim, R., I. J. Øien \& G. Sonerud 2015. Hva gjør lappuglene når smågnagerne uteblir? Vår Fuglefauna 38: 118-123. (Norwegian).

Stefansson, O. 1997. Nordanskogens vagabond. Lappugglan. Ord \& visor förlag, Skellefteå.

Stefansson, O. 2001-2013 Supplement No 1-1V (Swedish). Accessible from the website www.lappugglan.se

Sulkava, S \& Huhtala, K 1997. The Great Grey Owl (Strix nebulosa) in the changing forest environment of northern Europe. Journal of Raptor Research 31: 151-159.

Suopajärvi, P. \& M. Suopajärvi 1994. Lapinpöllön iän määrittäminen (Aging of the Great Grey Owl; Finnish with English summary). Linnut 29 (2): 27-30.

Valkama, J., P. Saurola, A. Lehikoinen, E. Lehikoinen, M. Piha, P. Sola \& W. Velmala 2014. The Finnish bird ringing atlas. Vol. II. Finnisk Museum of Natural History and Ministry of Environment, Helsinki.

\section{Sammanfattning}

Lappugglan Strix nebulosa lapponica har expanderat $i$ en sydlig och sydvästlig riktning sedan sent 1990-tal i det nordvästra hörnet av sin palearktiska utbredning (Lawicki et al. 2013). Expansionen söderut i Fennoskandia började mellan mitten av 1960-talet och början av 1990-talet (Stefansson 1997, Sulkava \& Huhtala 1997, Solheim 2009). Efter den första kända häckningen i östra Norge 1989 ökade rapporterna om observationer av lappugglor även i Norge (Solheim 2009). Antalet registrerade bon med häckningar eller häckningsförsök formligen exploderade i Norge efter 2009 vilket resulterade i mer än 60 bon med häckande lappugglor i Hedmark fylke 2014 (Solheim 2014a, Berg 2015).
Eftersom denna expansion är nära sammankopplad med lappugglans uppträdande och förekomst i Sverige tänkte vi att en mer detaljerad analys och presentation av det svenska ringmärkningsmaterialet skulle kunna ge värdefull bakgrundsinformation i försöken att förstå denna utveckling. Den nyligen publicerade Finnish Bird Ringing Atlas (Valkama et al. 2014) inspirerade till andra analyser än tidigare presenterade (Stefansson 1997 och supplementen 1-4, 2001-2013, Fransson et al. 2008).

Trots sin imponerande storlek lever lappugglan nästan uteslutande på små däggdjur med sorkar Microtus som det dominerande bytesdjuret följt av långsvansad skogssork Myodes glareolus och vanlig näbbmus Sorex araneus (Mikkola 1983, Stefansson 1997). Deras spridning och rörelser bör således förväntas följa ett mönster som liknar vad som hittats hos sorkspecialisten pärlugglan Aegolius funereus (Sonerud et al. 1988) och som varierar beroende på sorkcyklerna med toppar vart 3-4 år i de boreala delarna av Fennoskandia (e.g. Hanson \& Henttonen 1985, Sonerud 1988). Antalet registrerade häckningar av lappugglor blir följdriktigt störst vid toppen av sorkcyklerna vart 3-4 år (Mikkola 1983).

\section{Material och metoder}

Förteckningar över kontrollerade (levande) och återfunna (döda) lappugglor i Sverige presenterades först av Stefansson i boken "Nordanskogens vagabond" (1997) och senare med fyra supplement för åren 1997-2012. Detta inklusive material med kontroll- och återfyndsdata till och med år 2015 utgör grunden för våra sammanställningar. Vi har inte analyserat spridningsriktning utan koncentrerat oss på flyttningsavstånd och fåglarnas ålder vid kontrollerna och återfynden. Tidigare presenterade data har granskats och uppdaterats för att korrigera förekommande fel. Femton lappugglor ringmärkta i Finland har kontrollerats (9) eller återfunnits döda (6) i Sverige samtliga under 1984-2015. Data från dessa individer har införlivats i presentationen av ålder vid första häckning och spridningsavstånd.

\section{Resultat}

Från 1955 till 1996 har totalt 1715 lappugglor ringmärkts i Sverige (Stefansson 1997). 1997-2012 blev sammanlagt 1358 ringmärkta (Tabell 1) vilket ger totalt 3073 ringmärkta lappugglor som grund för vår analys. Av dessa har totalt 416 individer kontrollerats vid ett eller flera tillfällen (227, $54,6 \%)$ eller återfunnits döda $(189 ; 45,4 \%$ Figur 
1) vilket ger en återfyndsgrad av 13,5\%. För den senare perioden har materialet delats upp i fåglar ringmärkta som boungar $(1083,79,7 \%)$ och vuxna $(275,20,3 \%)$. För perioden 1997-2012 har återfynden delats upp i år de ringmärktes (Tabell 1) med återfyndsprocent för varje årsklass varierande från 4,3\% till 50,0\%. De tre åren med högst återfyndsprocent $(1997,2000$ och 2012) är år med några av det lägsta antalet ringmärkta individer $(13,9$ respektive 8). Även om endast åtta ungar ringmärktes dessa år kontrollerades faktiskt en av dem levande medan ingen återfanns död (Tabell 1). Av 16 ringmärkta som vuxna under dessa tre år kontrollerades tre senare levande medan sex återfanns döda. Den totala återfyndsgraden (döda och levande kontroller) från perioden 1997-2012 är 10,9\%.

122 lappugglor ringmärkta som ungar återfanns senare döda varav tre under sitt 17:e kalenderår (Figur 2). De flesta återfanns emellertid under deras första (33) eller andra (25) kalenderår medan antalet återfunna stadigt minskande därefter. Återfynden av döda lappugglor ringmärkta som häckande (vuxna) bestod av 39 honor och 8 hanar som också visar minskande antal återfynd med åldern (Figur 3). Den äldsta fågeln från denna grupp var en hona som återfanns 12 år efter ringmärkningen. Den exakta åldern är emellertid inte känd eftersom åldern hos vuxna lappugglor enligt ruggningsmönster (Suopajärvi \& Suopajärvi 1994, Solheim 2011) inte var känd vid tidpunkten för ringmärkningen vilket gäller de flesta vuxenmärkta ugglorna i detta material.

76 honor och 27 hanar ringmärkta som ungar kontrollerades senare som häckande minst en gång (Figur 4). De flesta kontrollerades för första gången i deras fjärde kalenderår eller senare. Fyra honor påträffades häckande som ettåriga $(2 \mathrm{~K})$ och fyra honor samt en hane som tvååriga $(3 \mathrm{~K})$. Den äldsta som påträffades häckande för första gången var en hona som kontrollerades i sitt 17:e kalenderår (16 år gammal). 91,3\% av alla kontrollerade var häckande fåglar ringmärkta som ungar och minst tre år gamla $(4 \mathrm{~K}+)$ när de kontrollerades häckande för första gången. Figur 4 visar en tendens till flera toppar av fåglar som kontrollerats i åldersklasserna $4 \mathrm{~K}-5 \mathrm{~K}, 7 \mathrm{~K}-8 \mathrm{~K}$ och $11 \mathrm{~K}-12 \mathrm{~K}(13 \mathrm{~K})$.

Ungfåglarnas spridning redovisas i Figur 5. 50 av totalt 52 unga lappugglor återfanns döda eller kontrollerades mellan 1 augusti och 30 juni följande år mindre än $250 \mathrm{~km}$ från där de ringmärktes som ungar. En av dem påträffades död $410 \mathrm{~km}$ från födelseplatsen och en sköts i Ryssland $420 \mathrm{~km}$ bort. Fåglar återfunna före utgången av september hittades mestadels mycket nära födelseplatsen. Det genomsnittliga avståndet för 29 fåglar som påträffades döda efter september var 100,8 km med ett medianavstånd av $64 \mathrm{~km}$. 10 ungfåglar kontrollerades mellan den 23 januari och 2 juni i deras andra kalenderår. Två av dem kontrollerades 126 km respektive $103 \mathrm{~km}$ från födelseplatsen medan övriga kontrollerades inom $80 \mathrm{~km}$. Det genomsnittliga flyttningsavståndet för dessa kontrollerade fåglar var $45.9 \mathrm{~km}$, med ett medianavstånd av $23 \mathrm{~km}$.

De adulta fåglarnas spridning visas i Figur 7-9. 103 lappugglor ringmärkta som ungar kontrollerades senare som häckande ( 76 honor och 27 hanar). Den maximala natalspridningen, alltså för fåglar registrerade som häckande för första gången, som registrerats var en hona ringmärkt 1982 och kontrollerad 1987 (6K) och som flyttat $650 \mathrm{~km}$. Nästa i raden var en annan hona kontrollerad som $13 \mathrm{~K}$ efter $230 \mathrm{~km}$. Det genomsnittliga avståndet natalspridning för alla vuxna visas länkade till fågelns ålder vid första kontrollen (Figur 6) och varierade mellan $29,9 \mathrm{~km}$ och 114,4 km. För enbart honor varierar natalspridningen mellan $30,8 \mathrm{~km}(7 \mathrm{~K})$ och 151,5 $\mathrm{km}(10 \mathrm{~K})$ med ett medelvärde av $72,3 \mathrm{~km}$ (Figur 7). Medianvärdet för honornas natalspridning låg mellan $7 \mathrm{~km}$ och $115 \mathrm{~km}$ med ett medelvärde av 40 $\mathrm{km}$. Det lägsta värdena för natalspridning hos de svenska lappugglehonorna fanns $\mathrm{i}$ åldersklasserna $2 \mathrm{~K}, 5 \mathrm{~K}, 8 \mathrm{~K}$ och $11 \mathrm{~K}$.

Totalt 135 honor (26 ringmärkta som ungar och 109 som häckande) kontrollerades som häckande mer än en gång, vissa upp till 6 gånger, vilket resulterar i totalt 211 kontroller av avstånd mellan deras första och senare boplatser (Figur 8) och omfattar 1-12 år efter den första registrerade häckningen. Medelvärdet av spridningsavståndet efter att ha häckat första gången varierar mellan $2,9 \mathrm{~km}$ och $101,8 \mathrm{~km}$ med en genomsnittlig spridning av 19,6 $\mathrm{km}$. Medianvärdet för den sekundära spridningen är mycket lågt och varierande mellan 0 och $9 \mathrm{~km}$. Endast nio hanar kontrollerades som häckande efter den första kontrollen som häckande vilket resulterade i endast 14 kontroller. Både medelvärdet och medianvärdet av sekundärt spridningsavstånd för hanar är mindre än $3 \mathrm{~km}$ (Figur 9) inom spannet 1-7 år efter den första registrerade häckningen.

\section{Diskussion}

Antalet lappugglor ringmärkta i Sverige 19112012 (3091; Fransson et al. 2013) är närmast identisk med antalet ringmärkta i Finland 1913-2012 (3110; Valkama et al. 2014). Det svenska materialet innehåller emellertid nästan dubbelt så många återfunna och kontrollerade individer (398 respek- 
tive 201). Antalet fåglar kontrollerade i Sverige t.o.m. 2012 är nästan fyra gånger så stort som i det finska materialet (262 kontra 69). För fåglar ringmärkta som ungar och senare kontrollerade som häckande är skillnaden ännu större med 97 individer som kontrollerats i Sverige och endast 18 i Finland. Dessa skillnader kan endast förklaras av en högre ansträngning på att fånga och kontrollera vuxna lappugglor i Sverige. Det högre antalet återfunna döda utav svenskmärkta lappugglor (189 kontra 123) kan kopplas till att Sverige har nästan dubbelt så många invånare än Finland $(9,8$ kontra 5,5 miljoner), vilket ger högre sannolikheter för att en död lappuggla påträffas.

De högsta återfyndsprocenten finns bland lappugglor ringmärkta under typiska bottenår hos sorkarna, år när endast ett litet antal fåglar ringmärktes (8, 9 och 13). Man kan förvänta sig en högre sannolikhet för att svältande individer påträffas under sådana år. Det är därför förvånande att den enda återfunna fågeln från dessa år var en ringmärkt som unge och som faktiskt kontrollerades häckande två år senare. De vuxna följer däremot förväntade mönster med sex återfunna döda och tre kontrollerade individer av 16 ringmärkta.

Spridningen av lappugglor ringmärkta som ungar och senare återfunna döda följde ett förväntat mönster med de flesta individer återfunna under sin första höst efter kläckningen och antalet stadigt minskande därefter (Figur 2). Eftersom de flesta ungar är ringmärkta under sorkarnas toppår (men några även i det föregående uppgångsåret), möter de som regel en sorkkrasch som $2 \mathrm{~K}$ (eller $3 \mathrm{~K}$ ) fåglar. Många möter en begynnande sorktillväxt som $3 \mathrm{~K}$ fåglar och märkbart som $4 \mathrm{~K}$ fåglar. Det låga antalet döda fåglar i åldersklasserna $3 \mathrm{~K}$ och $4 \mathrm{~K}$ kan således förklaras av en högre överlevnad hos fåglar som har överlevt de första två åren av sitt liv. Även fåglar ringmärkta som häckande vuxna och som senare återfunnits döda hittas mest sannolikt under det första året efter ringmärkningen (Figur 3 ). Det totala antalet återfunna vuxna är dock för litet för att kunna dra någon annan slutsats än att den äldsta överlevt 12 år efter ringmärkningen. Eftersom de flesta fåglar ringmärkta som ungar och senare kontrollerats som häckande fåglar var minst i åldersklassen $4 \mathrm{~K}$ eller äldre (Figur 4) kan denna individ mycket väl ha levt till 16 år. Detta är i enlighet med åldern hos den äldsta häckande lappugglan som kontrollerades för första gången (Figur 4) och matchar åldersrekordet i det finska materialet (16 år; Valkama et al. 2014).

Kontrollerna av häckande lappugglor ringmärkta som ungar visar att åtminstone några honor häcka- de redan som ettåriga (Figur 4) och minst en hane vid två års ålder. Cramp (1985) anger att den genomsnittliga åldern för första häckningen inte är känd men refererar till Stefansson om ålder hos den första registrerade häckningen för en hona häckande som ett år gammal fågel (2K).

Det högsta antalet som kontrollerats för första gången som vuxna finns i ålderskategorin $4 \mathrm{~K}$. Detta överensstämmer med en sorkcykeltopp efter tre år. Intressant är också topparna som återkommer för fåglar i ålderskategorin $7 \mathrm{~K}-8 \mathrm{~K}$ och som även tenderar att visa en topp för åldrarna $11 \mathrm{~K}-13 \mathrm{~K}$. Siffrorna för dessa sistnämnda åldersgrupper är dock små och kan påverkas av tillfälliga händelser. Topparna för åldersgrupperna $4 \mathrm{~K}$ och $7 \mathrm{~K}-8 \mathrm{~K}$ följer emellertid vad som kan förväntas vid sorkcykler med toppår vart 3-4 år.

I Finland återfanns flest ungfåglar under deras första år mindre än $50 \mathrm{~km}$ från deras födelseplats. Ungfåglar som senare kontrollerades påträffades emellertid närmare deras födelseplats än de som återfanns döda (Figur 5). Detta kan ha orsakats av att dessa individer var bättre utvecklade som jägare eller att tillgången på bytesdjur var förhållandevis god nära födelseplatsen när sorktillgången senare gick ner men kan också kopplas till att ringmärkaren var mer aktiv med att fånga och kontrollera fåglar i närheten av lokalerna där de ringmärkte dem som ungar.

Fåglar ringmärkta som ungar och senare kontrollerade som häckande visar medelvärden av natalspridning mellan $30 \mathrm{~km}$ och $144 \mathrm{~km}$ (Figur 6) vilket är i samma storleksordning som för ungfåglar återfunna döda under första levnadsåret. Medianvärdet för natalspridning för finska fåglar ringmärkta som ungar var $48 \mathrm{~km}$ för honor $(\mathrm{n}=13)$ och $25 \mathrm{~km}$ för hanar $(\mathrm{n}=5)$. Detta är i enlighet med ett övergripande median natalspridningsavstånd på $40 \mathrm{~km}$ för svenska honor. Det lägsta median natalspridningsavståndet hos honor i åldersklasserna $2 \mathrm{~K}, 5 \mathrm{~K}, 8 \mathrm{~K}$ och $11 \mathrm{~K}$ (Figur 7) kan också tolkas som ett resultat av sorkcyklernas topp vart tredje år, som dokumenterats för norra Sverige (Hipkiss et. al 2008). Honorna som häckar som $2 \mathrm{~K}$ fåglar möter då förmodligen en sorktopp året efter att de har kläckts och sprider sig därför kortare avstånd från födelseplatsen. Därefter kan det vara så att honorna vänder tillbaka till trakterna där de kläcktes eller tidigare har häckat.

När ugglorna har häckat för första gången är både honor (Figur 8) och hanar (Figur 9) ofta trogna häckningsplatsen eller har avstånd till nästa häckningsplats på maximalt $9 \mathrm{~km}$ för honor och 3 $\mathrm{km}$ för hanar. 34 honor i Finland som kontrollera- 
des i två på varandra följande häckningssäsonger flyttade också mindre än $10 \mathrm{~km}$. Medan svenska honor påträffats häcka i samma område upp till 12 år efter den första kontrollen (maximalt flyttavstånd var $102 \mathrm{~km}$ ) visade finska honor en median spridning av $67 \mathrm{~km}$ med högst $405 \mathrm{~km}$ förflyttning.

Under den mycket dåliga sorktillgången 2012 som täckte större delen av Fennoskandia var minst $76 \%$ av 144 individer 2K-fåglar identifierade från fotografier av lappugglor i Sverige (Solheim 2014b). Äldre fåglar visar sig emellertid också regelmässigt längs kusten i södra Norge och Sverige (Solheim 2010) vilket lämnar frågan öppen om huruvida gamla fåglar stannar i närheten av sina häckningsplatser under vintern eller migrerar mer eller mindre långt till andra eventuellt bättre jaktmarker innan de evantuellt återvänder till häckningsområden de har använt minst en gång. För att få mer data på vinterrörelser inleddes ett satellitprojekt år 2014 och två i östra Norge häckande honor utrustades med sändare (Solheim et al. 2015). En av dem uppehöll sig inom 26 km från 2014 års häckningsplats från februari 2015 tills den förlorade sändaren i slutet av maj samma år. Den andra flyttade till en ny lokal $175 \mathrm{~km}$ bort där den stannade i ett år tills sändaren tystnade i februari 2016. Förhoppningsvis ger fler fåglar med sändare bättre data om lappugglornas vintervanor i framtiden. 